\title{
Efficiency Profiles of Vegetable Producers in Akwa Ibom State, Southern Nigeria
}

\author{
Idiong Christopher Idiong ${ }^{1}$, Inibehe George Ukpong ${ }^{2}$ \& Etim Okon Effiong ${ }^{3}$ \\ ${ }^{1}$ Department of Agricultural Economics and Extension, University of Calabar, Nigeria \\ ${ }^{2}$ Department of Food Economics and Marketing, School of Agriculture, Policy and Development, University of \\ Reading, Whiteknights, Berkshire, United Kingdom \\ ${ }^{3}$ Department of Agricultural Economics and Extension, University of Uyo, Nigeria \\ Correspondence: Inibehe George Ukpong, Department of Food Economics and Marketing, School of Agriculture, \\ Policy and Development, University of Reading, Whiteknights, Berkshire, RG6 6AR, United Kingdom. Tel: \\ 44-740-479-3722. E-mail: inibeheukpong@gmail.com
}

Received: November 17, 2013 Accepted: January 13, 2014 Online Published: January 20, 2014

doi:10.5539/sar.v3n1p60 URL: http://dx.doi.org/10.5539/sar.v3n1p60

\begin{abstract}
Vegetables are among the major staple foods in Southern Nigeria. This study assessed the efficiency profiles of vegetable producers in Akwa Ibom State, Southern Nigeria with specific focus on farm level technical efficiency. One hundred and twenty (120) vegetable producers were randomly selected from three agricultural zones in the State. The Maximum Likelihood Estimates (MLEs) indicate positive relationships between input variables used by farmers and farm outputs. The Generalized Likelihood Ratio test confirms that vegetable producers in the area are relatively technically inefficient. The technical efficiency of the farmers ranged from 48 to 99 percent with a mean of 70 percent. The implication is that there is allowance to improve efficiency with available resource.There is, therefore, the need for policies to promote the availability of affordable farm inputs and technology to help improve farmers' efficiency and increase vegetable production in the area. Extension services would also help provide useful information to the farmers on farm practices that would enhance output and ensure environmental sustainability of the production process by maintaining the quality of some critical environmental factors especially soil quality.
\end{abstract}

Keywords: efficiency, vegetable, Akwa Ibom, southern Nigeria

\section{Introduction}

Efficiency implies an economic state in which every resource is optimally allocated to serve each person in the best way while minimizing wastes and inefficiency (Costa, 2012). It also implies the ability to produce a good or service using the fewest resources possible, hence an efficient production is achieved when a product is created or produced at its lowest average total cost (Akpan, 2006). Analysis of production efficiency is important to ensure resource maximization and sustainable use of available resources when creating utility. The essence of production is to produce a product or service which may be in the form of food or any other form that has the potentials to create utility at minimum cost. However, such production needs to be done in an efficient way. Abang et al. (2008) confirmed that one of the basic interests of the farm manager is to select the combination of resources that will produce a given quantity of output at the minimum cost. Production efficiency can be measured as technical, allocative or economic efficiency. Technical efficiency is associated with physical economies of scale and involves the measurement of the firms' success in producing maximum output from a given set of inputs, while allocative efficiency is the ability to choose the optimum input level given factor prices. Economic efficiency of production implies the production of outputs (goods and services) at their lowest possible cost of the variable inputs (factors) of production. In other words, economic efficiency encompasses both the technical and allocative efficiencies (Farell, 1957). In Nigeria, agricultural production centers mostly on food crops as well as livestock, fisheries and forestry products. Food crops produced in the country include cassava, yam, plantain and cereals such as rice, maize, millet, sorghum and wheat. Also, various kinds of vegetables are produced in Nigeria, most of which are among the staple food in the country. However, yields of food crops in the country, including vegetables often fluctuate with varying estimated annual production statistics. It becomes necessary to study the efficiency of food crop production in the country, by assessing the 
profiles of producers in terms of resource use.

In Nigeria, food crop production, including vegetables is dominated by small scale farmers, mostly women who still use traditional farming systems and crude implements, which alongside their varying socioeconomic characteristics have influence on their efficiency in production and resource use. Vegetables are of great nutritional value and important sources of vitamins and minerals, and dominate the diets of most Nigerians. For instance, in Akwa Ibom State, vegetables such as pumpkins (Telferia occidentalis) and water leaf (Talinum fruticosum) receive high popularity due to their high consumption demands by people in the area. These vegetable crops form the major types of vegetables commonly cultivated by both rural farmers and those into urban or backyard food crop production in the area (Mbanasor \& Kalu, 2008). Moreover, inefficiency in resource use can result to low productivity in food crop production. As Nigeria's population continues to increase; there is a high need to ensure efficient food production to promote food security with sustainable use of resources. In other words, since resources are limited, being able to produce efficiently allows for higher levels of production. It is important to produce as much as possible without wasting available resources, hence, the need to improve the production efficiency of the farmers. Efficient production, therefore, will not only prevent wastage, but also help make more food available to meet high food demands in the country. This study therefore was aimed at estimating a production function for leafy vegetable producers in the study area and determining their levels of efficiency, as well as proffering recommendations based on findings.

\section{The Concepts of Production Efficiency}

The best production process should involve the use of fewer inputs and being technically more efficient. Efficiency implies an economic state in which every resource or a combination of inputs is optimally allocated to produce maximum outputs while minimizing waste and inefficiency in the production process. It also implies the ability to produce a good or service using the fewest resources possible, hence, an efficient production is achieved when a product is created or produced at its lowest average total cost (Akpan, 2006). The identification of the concepts of production efficiency is therefore, important, for instance, analysis of technical and allocative efficiency can be helpful for policy formulation and economic decisions aimed at achieving maximum outputs with minimum inputs while ensuring resource sustainability. In other words, the knowledge of the production function of a given agricultural enterprise, for example, the fisheries, animals and crops, would enable the formulation of a response to future changes that might occur, including; reduction of the labour force and technological innovations, as well as, the possibility and extent to substitute one input for another, with a view to achieve maximum production efficiency (FAO, 1999). Moreover, the existence of technical inefficiency enables identification of the sources of inefficiencies in production (Giroh, Valla, Mohammed, \& Peter, 2008).

Efficiency of production is therefore, usually considered in different forms such as technical and allocative efficiencies (Tsue, Lawal, \& Ayuba, 2012), and in a broader context, in terms of economic efficiency. Yotopoulos and Lau (1973) explained that economic efficiency can be decomposed into two components, including technical efficiency and price efficiency. Technical efficiency is associated with physical economics of scale and involved the measurement of the firms' success in producing maximum output from a given set of inputs, while allocative efficiency is the ability to choose the optimum input level given factor prices (Farrell, 1957). In other words, technical efficiency describes "the physical ratio of product output to the factor inputs" (Adewale \& Aromolaran, 2009). Economic efficiency of production, therefore, implies that goods are produced at their lowest possible cost of the variable inputs used in the production process.

\section{Methodology}

This study was carried out in Akwa Ibom State in Southern Nigeria. The State is bounded on the North by Cross River and Abia States and in the South by the Atlantic Ocean. To the East, it is bounded by Cross River State and in the West by Rivers and Abia States. It has a land area of $7081 \mathrm{~km}^{2}$ and an estimated population of over 4.8 million people (NPC, 2006) spread over 31 Local Government Areas (LGAs). The State lies within the tropical rainforest belt; hence it has a longer rainy season in April to November while dry season lasts only from December to March. The State has very rich potential for agriculture supported by its numerous water resources including rivers, ponds and streams. The rivers support a wide range of irrigation farming and fishing, while its green vegetation also supports livestock farming. Crops widely grown include food crops such as yam, swamp rice, cassava, cocoa yam, plantain, banana and vegetables such as, water leaf, fluted pumpkin, and garden egg. Tree crops common in the area include oil palm, citrus, rubber and mango. There are also numerous forest reserves in different areas within the State useful for a wide range of forestry activities to support the livelihood of the rural people. 


\subsection{Sampling Procedure and Sample Size}

A multi-stage sampling procedure was employed to select the sample size needed for the study. In the first stage, three areas in the State, namely; Ikot Ekpene, Uyo and Eket were purposively selected given the intensity of vegetable production in these locations. In the second stage, assistance of Extension officers was employed to help identify fifty (50) vegetable producers in each of the locations selected for the study. A total of one hundred and fifty vegetable producers were contacted for the study. Only waterleaf producers and farmers who also produce waterleaf among the major crops grown in the area were selected and interviewed for the study. In the final stage, one hundred and twenty (120) of the waterleaf producers (40 farmers in each location) were interviewed for the study.

\subsection{Data and Methods of Collection}

Primary data obtained on vegetable production included; output of vegetable production per farmer, type and amount of labour used, value of rent for land, quantity of fertilizer and or manure used as well as capital. The outputs of waterleaf were obtained in their local measures (bundles) which were later converted to the standard units of the kilogramme. The data obtained covered the previous year's production season and was done using interview schedules.

The study applied the concepts of the stochastic frontier production model (Aigner, Lovell, \& Schmidt, 1977) for food crop as used in (Lovell, 1993; Greene, 1993), this can be specified as follows:

$$
Q=f\left(X_{i}\right)+\varepsilon_{i}
$$

and,

$$
Q=\alpha+\beta X_{i}+\varepsilon_{i}
$$

Where,

$\mathrm{Q}=$ Output of food crop in ith farm

$\mathrm{X}_{\mathrm{i}}=$ Vector of inputs used by ith farmer

$\beta=$ Vector of unknown parameters

$\alpha=$ Intercept

$\varepsilon_{\mathrm{i}}=$ Error term

A Cobb-Douglas function was fitted to the stochastic frontier production function and estimated. The vegetable production function is specified as follows;

$$
\operatorname{Ln} Y=\operatorname{Ln} \beta_{0}+\beta_{1} \operatorname{Ln} X_{1}+\beta_{2} \operatorname{Ln} X_{2}+\beta_{3} \operatorname{Ln} X_{3}+\beta_{4} \operatorname{Ln} X_{4}+\beta_{5} \operatorname{Ln} X_{5}+\varepsilon_{\mathrm{i}}
$$

Where,

$\mathrm{Ln}=$ natural logarithm

$\mathrm{Y}=$ output of vegetable $(\mathrm{Kg})$

$\mathrm{X}_{1}=$ farm size (hectares)

$\mathrm{X}_{2}=$ labour input (man-days)

$\mathrm{X}_{3}=$ capital investment (Nigerian Naira)

$\mathrm{X}_{4}=$ Manure/fertilizer $(\mathrm{Kg})$

$\mathrm{X}_{5}=$ planting materials (Naira)

$\beta_{0}=\mathrm{Y}-$ intercept

$\beta_{1}, \beta_{2}, \beta_{3}, \beta_{4}$ and $\beta_{5}$ are coefficients to be estimated. $\varepsilon_{\mathrm{i}}=$ Error term as defined in Equations (1) and (2). 


\section{Results and Discussion}

Table 1. Summary statistics of output and inputs used by leafy vegetable producers in Akwa Ibom State

\begin{tabular}{cccc}
\hline Variables & Unit & Mean & Standard Deviation \\
\hline Output $(\mathrm{Y})$ & $\mathrm{Kg}$ & 5879.75 & 43.05 \\
Farm size $\left(\mathrm{X}_{1}\right)$ & $\mathrm{Ha}$ & 0.0543 & 0.01 \\
Labour $\left(\mathrm{X}_{2}\right)$ & Man-days & 121.54 & 64.74 \\
Capital $\left(\mathrm{X}_{3}\right)$ & Naira & 2045.24 & 54.81 \\
Manure/fertilizer $\left(\mathrm{X}_{4}\right)$ & $\mathrm{Kg}$ & 28.25 & 12.05 \\
Planting materials $\left(\mathrm{X}_{5}\right)$ & Naira & 7445.5 & 23.42
\end{tabular}

Source: Computed from field survey data, 2010.

Table 1 shows the summarized statistics of the mean levels of output and inputs used by the vegetable (waterleaf) producers in the study area. The average output by a vegetable producer in the study area was 5879.75 kilograms of waterleaf during the production period, while the average farm size for cultivation of vegetables was about 0.05 hectares indicating the small scale nature of vegetable production in the area. The results also show that the producers used about 121.54 man-days of labour mainly from family labour due to the high cost of hired labour in the area. Average capital invested by the vegetable producers on their farms was 2045.24 Nigerian Naira. This is an indication of low external input use in vegetable production in the area. In terms of planting materials, they used about 7445.5 Nigerian naira worth of it while using about 28.25 kilograms of fertilizer combined with manure. The limited use of these inputs, and the continuous cropping of vegetables on the same parcels of land over time, can result in nutrient mining which would adversely affect crop yields.

Table 2. Maximum Likelihood estimates of the stochastic production frontier function for vegetable producers in Akwa Ibom State

\begin{tabular}{llll}
\hline Variables & Coefficients & Standard errors & t-ratios \\
\hline Intercept & 2.3242 & 0.3094 & $7.51^{* * *}$ \\
Farm size $\left(\mathrm{X}_{1}\right)$ & 1.2443 & 0.5335 & $2.33^{* *}$ \\
Labour $\left(\mathrm{X}_{2}\right)$ & 0.4376 & 0.1889 & $2.32^{* *}$ \\
Capital $\left(\mathrm{X}_{3}\right)$ & 0.0456 & 0.0591 & 0.77 \\
Manure/fertilizer $\left(\mathrm{X}_{4}\right)$ & 0.1897 & 0.0564 & $3.36^{* * *}$ \\
Planting materials $\left(\mathrm{X}_{5}\right)$ & 0.6554 & 0.2471 & $2.65^{* *}$ \\
Returns to Scale (RTS) & 2.5726 & & \\
Gamma $(\gamma)$ & 0.919 & 0.285 & $4.68^{* * *}$ \\
Sigma square ( $\left.\sigma^{2}\right)$ & 0.754 & 0.043 & $3.78^{* * *}$ \\
Log Likelihood Function & 87.45 & & \\
Log likelihood Ratio (LR) & 32 & & \\
\hline
\end{tabular}

Note: *** Significant at $1 \%$ level, ** Significant at $5 \%$ level.

Source: Computed from field survey data, 2010.

Table 2 shows the Maximum Likelihood Estimates (MLEs) of the Cobb-Douglas stochastic production frontier function for vegetable (waterleaf) producers in Akwa Ibom State. The results show that the coefficient of farm size $\left(\mathrm{X}_{1}\right)$ is positive and significant at the 5 percent level. This implies that increase in farm size will result in increased output of vegetables in the area. The coefficient of labour $\left(\mathrm{X}_{2}\right)$ also has a positive sign and significant at 5 percent implying that increase in labour will result to an increase in output. To cope with high labour demand associated with vegetable production, most farmers resort to the use of family labour in order to cut cost 
of hired labour. However, increased use of family labour can result to labour saturation and lower returns on labour use and inefficiency.

Capital $\left(\mathrm{X}_{3}\right)$ had no significant coefficient although it was positive on a priori basis. The coefficients of Manure/fertilizer $\left(\mathrm{X}_{4}\right)$ and planting materials $\left(\mathrm{X}_{5}\right)$ were also positive and significant at one and five percent levels respectively, this implies that the increase in these variables $\left(\mathrm{X}_{4}\right.$ and $\left.\mathrm{X}_{5}\right)$ will significantly increase the output of vegetables in the study area.

The elasticity of production with respect to farm size, labour, capital, manure/fertilizer and planting materials indicate that a one percent increase or decrease in these variables will lead to $1.2443,0.4376,0.0456,0.1897$ and 0.6554 percent respectively. The sum of the elasticities (2.57); shows an increasing return to scale. This implies that the vegetable producers were operating within the stage 1 of the production function.

The value of the sigma-square $\left(\sigma^{2}=0.75\right)$ is large and significantly different from zero indicating the goodness of fit and correctness of the specified assumptions of the distribution of the composed error term (ći). The gamma $(\gamma)$, is also very high (0.912) and significant at the one percent level which indicates that influences which are not explained by the production function are the major sources of random errors. It also shows that 91 percent of the variation in the output of vegetables in the study area is as a result of inefficiency in resource utilization.

Table 3. Efficiency distribution of the vegetable producers in Akwa Ibom State

\begin{tabular}{lll}
\hline Efficiency class & No. of producers & Percentage \\
\hline Less than 50 & 10 & 8.33 \\
$50-60$ & 8 & 6.67 \\
$61-70$ & 17 & 14.17 \\
$71-80$ & 34 & 28.33 \\
$81-90$ & 44 & 36.67 \\
91 and above & 7 & 5.83 \\
\hline Total & 120 & 100 \\
Mean & 70 & \\
Standard deviation & 31.43 & \\
Minimum & 48 & \\
Maximum & 99 &
\end{tabular}

Source: Computed from field survey data, 2010.

Table 3 shows the distributions of the technical efficiencies of the vegetable producers in the study area. The distribution shows a range from 48 percent to 99 percent. It also shows that the majority $(65 \%)$ of the producers were within the 71 to 90 percent efficiency levels and only about 5.83 percent were those with efficiency above 90 percent. The mean efficiency level of the producers was 70 percent. This value is higher than the $65 \%$, reported by Udoh and Akpan (2007) but slightly lower than the 72 percent reported by Umoh (2006) and 82 percent (0.82) by Bozoglu and Ceyhan (2007) in their studies. The relatively higher levels of technical efficiency of the Waterleaf producers is an indication that only a small fraction of the losses in their output can actually be attributed to resource wastage. From the results, it can be deduced that for the average vegetable producer (those with an efficiency level of 70 percent) to attain the technical efficiency level of the most efficient producer (those with an efficiency level of 99 percent); the farmer would realize; [1-(70/99)] x 100, that is, about 29.3 percent in cost savings. On the other hand, should the least technically efficient vegetable producer (those with an efficiency level of 48 percent) desire to achieve the level of the most efficient vegetable producer, the farmer would achieve cost savings of [1-(48/99)] x 100, that is, about 51.5 percent. 
Table 4. Generalized likelihood ratio test for technical efficiency of vegetable producers in Akwa Ibom State

\begin{tabular}{cccc}
\hline Likelihood Function & Log likelihood Ratio $(L R)(\lambda)$ & Critical Value $\left(\chi^{2} 0.05\right)$ & Conclusion \\
\hline 98.54 & 33.32 & 11.91 & Reject \\
\hline
\end{tabular}

Source: Derived from Table 3, Critical $\chi^{2}$ values were obtained from Kodde and Palm (1986).

Table 4 shows the result of the Generalized Likelihood Ratio Test (GLRT) used to test the hypothesis that vegetable producers in Akwa Ibom State are fully technically efficient $(\gamma=0)$. The result indicates the rejection of the null hypothesis of full technical efficiency (and the conclusion that vegetable producers in the study area are not fully technically efficient in resource use).

\section{Conclusion and Recommendations}

One of the major findings of this study is that vegetable producers in the study area are not fully technically efficient. However, there is the possibility to increase productivity of the farmers by improving their levels of efficiency with available resources and improved level of technology. This can be achieved by identifying variables that cause inefficiency in vegetable production in the area and making suitable policies that can address them. Such policies should make provision for availability of affordable farm inputs, farmers' training and improved technology to enhance increased vegetable production in the area. Extension services would also be important to help provide information to the farmers on farm practices that would not only enhance output but also ensure environmental sustainability of the production process. Since vegetables are among the staple food items in the area, improvement in vegetable production will help promote food security and improve the livelihood of the people, by also increasing the income of vegetable producers and making more vegetables available for household consumption and the markets.

\section{References}

Abang, S. O., Agom, D. I., Enyenihi, E. A., \& Ele, I. E. (2008). Introduction to Farm Management: Principles, Plans, Budgets and Control. King Judah Publishers, Calabar, Nigeria.

Adewale, T. I., \& Aromolaran, A. B. (2009). Micro-credit and Technical Efficiency in Food Crops Production: A Stochastic Frontier Approach: Adv. in Nat. Appl. Sci., 3(2), 156-165.

Aigner, D. J., Lovell, C. A. K., \& Schmidt, P. (1977). Formulation and Estimation of Stochastic Frontier Production Functions. Journal of Econometrics, 6, 21-37. http://dx.doi.org/10.1016/0304-4076(77)90052-5

Akpan, O. E. (2006). Economics of Production: Theory, Principles and Applications. Calabar: Wusen Press Limited.

Bozoglu, M., \& Ceyhan, V. (2007). Measuring the Technical Efficiency and exploring the Inefficiency determinants of Vegetable Farms in Samsun Province, Turkey. Agricultural Systems, 94(3), 649-656. http://dx.doi.org/10.1016/j.agsy.2007.01.007

Costa, A. L. (2012). Vehicle Miles Traveled (VMT) Fee Financing Alternatives: Lessons learned and Future Opportunities (p. 19). A Thesis submitted to the Graduate School, University of Massachusetts Amherst. Retrieved from http://scholarworks.umass.edu/do/search/?q=ashley\%20costa\&start=0\&context=179873

Food and Agricultural Organization (FAO). (1999). Micro-economic Analysis of Production. Fisheries and Aquaculture Department, Food and Agriculture Organization. Retrieved from http://www.fao.org

Farrell, M. J. (1957). The Measurement of Productive Efficiency. Journal of Royal Statistical Society (Series A: General), 120(3), 253-290. http://dx.doi.org/10.2307/2343100

Giroh, D. Y., Valla, W., Mohammed, A., \& Peter, O. (2008). Analysis of Technical Inefficiency of Gum Arabic Based Cropping patterns among Farmers in the Gum Arabic Belt of Nigeria. Journal of Agriculture and Social Science, 4(3), 125-128.

Green, W. H. (1993). The Econometric Approach to Efficiency Analysis. In The Measurement of Productive Efficiency: Techniques and Applications', H. O. Fried, C. A. K. Lovell \& S. S. Schmidt (Eds.). (pp. 132-145). New York: Oxford University Press.

Kodde, D. A., \& Palm, F. C. (1986). Wald criteria for jointly testing Equality and Inequalityrestrictions. Econometrica, 54(5), 1243-1248. http://dx.doi.org/10.2307/1912331

Lovell, C. A. K. (1993). Production Frontiers and Production Efficiency. In H. O. Fried, C. A. K. Lovell \& S. S. 
Schmidt (Eds.). The Measurement of Productive Efficiency (pp. 187-205). New York: Oxford University Press.

Mbanasor, J. A., \& Kalu, K. C. (2008). Economic Efficiency of Commercial Vegetable Production System in Akwa Ibom State, Nigeria: A Translog Stochastic Frontier Cost Function Approach. Tropical and Subtropical Agro-Ecosystems, 8, 313- 318.

National Population Commission (NPC). (2006). Population Data in Nigeria. National Population Commission of Nigeria. Retrieved from http://www.population.gov.ng

Udoh, E. J., \& Akpan, S. B. (2007). Measuring technical efficiency of waterleaf (Talinum triangulare) production in Akwa Ibom State, Nigeria. American-Eurasian Journal of Agriculture and Environmental Science, 2(5), 518-522.

Umoh, G. S. (2006). Resource use efficiency in urban farming. An Application of Stochastic Frontier Production Function. International Journal of Agriculture and Biology, 8(1), 37-44.

Tsue, P. T., Lawal, W. L., \& Ayuba, V. O. (2012). Profit Efficiency among Catfish Farmers in Benue State, Nigeria. African Journal of Food, Agriculture, Nutrition and Development, 12(6), 6759-6775.

Yotopoulos, P. A., \& Lau, L. J. (1973). A Test for Relative Economic Efficiency: Some further results. The American Economic Review, 63(1), 214-223.

\section{Copyrights}

Copyright for this article is retained by the author(s), with first publication rights granted to the journal.

This is an open-access article distributed under the terms and conditions of the Creative Commons Attribution license (http://creativecommons.org/licenses/by/3.0/). 